This article was downloaded by: [University of California, Irvine]

On: 12 August 2010

Access details: Access Details: [subscription number 918974203]

Publisher Psychology Press

Informa Ltd Registered in England and Wales Registered Number: 1072954 Registered office: Mortimer House, 3741 Mortimer Street, London W1T 3JH, UK

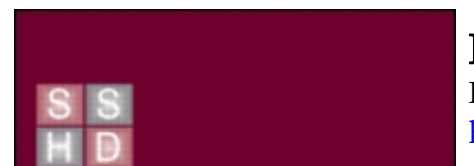

\title{
Research in Human Development
}

Publication details, including instructions for authors and subscription information:

http://www.informaworld.com/smpp/title $\sim$ content=t775653695

RESEARCH IN

HUMAN DEVELOPMENT

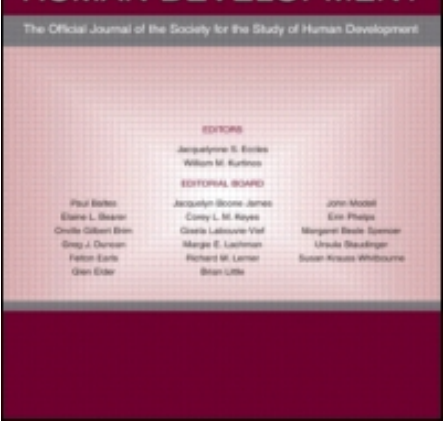

\section{Can Ambition Help Overcome Social Inequality in the Transition to} Adulthood? Individual Agency and Societal Opportunities in Germany and the United States

Jutta Heckhausen ${ }^{a}$; Esther S. Chang ${ }^{b}$

${ }^{a}$ University of California, Irvine, USA ${ }^{b}$ Soka University of America,

Online publication date: 01 December 2009

To cite this Article Heckhausen, Jutta and Chang, Esther S.(2009) 'Can Ambition Help Overcome Social Inequality in the Transition to Adulthood? Individual Agency and Societal Opportunities in Germany and the United States', Research in Human Development, 6: 4, $235-251$

To link to this Article: DOI: $10.1080 / 15427600903281244$

URL: http://dx.doi.org/10.1080/15427600903281244

\section{PLEASE SCROLL DOWN FOR ARTICLE}

Full terms and conditions of use: http://www.informaworld.com/terms-and-conditions-of-access.pdf

This article may be used for research, teaching and private study purposes. Any substantial or systematic reproduction, re-distribution, re-selling, loan or sub-licensing, systematic supply or distribution in any form to anyone is expressly forbidden.

The publisher does not give any warranty express or implied or make any representation that the contents will be complete or accurate or up to date. The accuracy of any instructions, formulae and drug doses should be independently verified with primary sources. The publisher shall not be liable for any loss, actions, claims, proceedings, demand or costs or damages whatsoever or howsoever caused arising directly or indirectly in connection with or arising out of the use of this material. 


\title{
Can Ambition Help Overcome Social Inequality in the Transition to Adulthood? Individual Agency and Societal Opportunities in Germany and the United States
}

\author{
Jutta Heckhausen \\ University of California, Irvine \\ Esther S. Chang \\ Soka University of America
}

\begin{abstract}
The regulation of human development requires the selection of developmental goals and focused investment of resources in their pursuit. Societally institutionalized and normative conceptions about developmental tasks and deadlines regulate some of this selectivity, but in modern societies with their substantial social mobility an important part is played by the individual agent. Societies and their educational systems differ in the degree to which they constrain versus facilitate upward mobility. Accordingly, individual goal setting is most effective when closely calibrated in societies with less permeable educational and vocational career paths. In contrast, goal setting that reflects high-flying ambitions is adaptive under societal conditions that offer greater permeability between educational tracks and that foster step-wise social climbing. Exemplary findings from two longitudinal studies of the transition from school to work and college and situated in two critically different societies, Germany and the United States, are discussed.
\end{abstract}

Address correspondence to Jutta Heckhausen, Dept. of Psychology and Social Behavior, University of California, Irvine, 4316 Social and Behavioral Sciences Gateway, Irvine, CA 92697-7085. E-mail: heckhaus@uci.edu 
When Lonnie Sherrod invited me to write a paper for this special issue in honor of Orville Gilbert Brim, I immediately thought of Bert Brim's long-standing interest in how individual agents win or loose in their endeavors across the life course, and particularly his fascination with human ambition (Brim, 1992). Having served as a MacArthur Foundation Network on Successful Midlife Development (MIDMAC) associate for several years, I had the opportunity to enjoy Bert's wisdom at a series of meetings of the MIDMAC on several of the Florida Keys, and also had the pleasure of co-authoring an article with him on the topic of adaptive social downgrading as a strategy to ward off burdening by age-related problems not only in old age, but also in midlife (Heckhausen \& Brim, 1997).

For my work on the role of motivation in life-span development, ambitiousness in human agency is a key topic. The motivational theory of life-span development developed in collaboration with Richard Schulz since the early 1990s investigates how individuals influence their own development by engaging with and disengaging from developmental goals (Heckhausen, 1999; Heckhausen, Wrosch, \& Schulz, in press; Heckhausen \& Farruggia, 2003; Heckhausen \& Schulz, 1993, 1995, 1999; Schulz \& Heckhausen, 1996; Schulz, Wrosch, \& Heckhausen, 2003). This article presents key conceptual positions of this theory as they relate to human agency in the life course and its opportunities and constraints as provided by the social context. Other authors in life-span developmental psychology (Brandtstädter, 2008; Little, Salmela-Aro, \& Phillips, 2007; Nurmi \& SalmelaAro, 2006) and in life-course sociology (Cote, 2002; Evans \& Heinz, 1994; Furlong, Cartmel, Biggart, Sweeting, \& West, 2006; Heinz, 2002; Hitlin \& Elder, 2007) have addressed the topic of human agency in the life course, but space limitations do not permit a differentiated discussion of similarities and differences between these approaches.

We focus on the transition from school to work and college as probably the most consequential transition in the life course. We consider differences between societies in the social permeability of their life-course paths. These differences should have consequences for the effectiveness of calibrated versus bluntly ambitious goal setting. This is illustrated by a set of exemplary findings from two longitudinal studies of the transition from school to work and college and situated in two critically different societies, Germany and the United States.

\section{INTERPLAY BETWEEN BIOLOGY, SOCIETY, AND INDIVIDUAL AGENT}

Individuals' development across the life course is shaped by an interplay between biological growth and decline, societal institutions and social structure, as well as individual agency (Heckhausen, 1999; Heckhausen \& Schulz, 1999). The relative role of these major influencing factors changes across history and varies across 
contemporary societies. In general, societies with greater technological development, division of labor, and expert specialization afford greater permeability of social segmentation, and thus provide greater opportunities for the individual to strive for upward social mobility. When bringing sociological perspectives and a motivational psychology approach to the life course together, an intriguing hypothesis emerges: Individual ambition should be more adaptive in some societies than in others, and the degree of individual ambitiousness may be effective or detrimental depending on the societal institutions that regulate upward mobility, most of which involve education.

\section{REGULATORY REQUIREMENTS IN DEVELOPMENT ACROSS THE LIFE COURSE}

In the course of behavioral evolution, and more specifically during the elaboration of open behavioral programs (Mayr, 1974), humans are unprecedented in the variability and flexibility of behavior and individual ontogeny. This is, of course, advantageous to adaptation, across generations and within an individual life span, but also bears some costs, most notably with regard to the regulation of behavior. An overall adaptive and thus reasonably stable higher order system of regulation needs to control behavior in such a way as to fulfill two requirements are fulfilled (Heckhausen, 1999; Heckhausen \& Schulz, 1999). First, strategies of selectivity help the individual to invest resources in accordance with opportunities and in an organized and focused way. Second, strategies of compensation help individuals to deal with failure experiences. In this article, we focus on the selectivity requirement and try to elucidate how individual agency and societal institutions and structure function together to regulate individuals' life courses.

The notion that successful development involves choosing or selecting certain domains or goals over others and then focusing one's investment on those chosen goals is part and parcel of life-span developmental theory (Baltes, 1987; Baltes \& Baltes, 1990; Carstensen, 1993). Adaptive selectivity involves choosing the right goal at the right time in life, namely when opportunities are favorable, and then focusing on the chosen goal. Both these aspects of selectivity can in principle be provided by societal institutions, or the individual agent, or a combination of both. In highly socially stratified and segmented societies (e.g., caste systems or the feudal system of medieval Europe), there is not much room for individual choice. People move along a timeline of developmental tasks (school and training, marriage, parenthood) fixed by societal prescription. Most modern societies, however, provide substantially more degrees of freedom, and thus choosing different paths is more up to the individual, particularly at the critical transitions that provide decision points between family of origin, school, college, and work.

Once a decision is made for a certain goal (e.g., attend 4-year college), it is up to the individual to commit his or her motivational and behavioral resources into 
pursuing the goal. Societal institutions and social contexts may be more or less helpful in scaffolding this motivational commitment and persistence. For example, parents with college degrees and high schools with a strong mission to support 4-year college enrollment can be expected to be more potent supporters of an adolescent's goal to apply for an academically high-quality college (Eccles \& Wigfield, 2002; Sewell \& Shah, 1968). However, individuals also vary in the degree to which they are willing and capable of marshalling their motivational commitment (Heckhausen \& Heckhausen, 2008).

\section{INDIVIDUAL AGENCY IN DEVELOPMENT AND SOCIETAL CONSTRAINTS}

Societies at different points in history as well as concurrently differ greatly with regard to the opportunities and risks they afford individuals who endeavor to move beyond the social class of their parents. In feudalistic times, most individuals were fixed at the social rank of their parents. This changed substantially with the rise of industrialization and specialized crafts in the increasingly influential cities of medieval Europe. The rise of manufacturing and industrial production, and the concomitant increase in division of labor and specialization, permitted dramatically increased social mobility between generations and within an individual's life course. One might imagine that today's globalized economy would maximize social mobility and optimize an individual's control and responsibility regarding developmental and life-course outcomes. However, the structure of social inequality in modern societies is still pronounced, and mechanisms of life-course canalization perpetuate social inequality across generations and within individual life courses. For example, across generations access to higher education can be facilitated, if parents have the relevant educational experience themselves. Climbing up the educational ladder is harder for first-generation college students than college students that can rely on their parents' experience and modeling of pursuing higher education.

Within individual life courses, people may be able to use a major life course transition (e.g., after graduating from high school) as a springboard to launch an upwardly mobile trajectory into a higher social stratum (e.g., by entering college and going on to medical school). Changing one's social position between normative life-course transitions (i.e., while being a student, within a given career) is probably less easily achieved, particularly in societies with less flexible career patterns, and might well involve an extraordinary event that either derails the individual in his or her path (e.g., by a severe illness, large inheritance) or disrupts societal canalization processes (e.g., by extensive societal transformation, such as associated with German reunification).

Societal canalization mechanisms within a system of social inequality have an ambivalent nature (Heckhausen, 1999; Heckhausen \& Schulz, 1999). On the one 
hand, they constrain an individual's upward mobility, and on the other hand they serve as adaptive scaffolds for individuals' developmental goal setting and goal engagement. Societal canalization via segmented labor markets segregated career paths with specific educational and vocational qualification, conveys predictability and allows the individual to plan ahead without having to deal with the imponderabilities of great chances for upward and risks for downward mobility. Moreover, societal canalization frees the individual from the necessity of constantly reevaluating his or her social standing and upward mobility potential, and it protects from an otherwise ubiquitous risk for downward social mobility. At least before the more recent destabilizing economic effects of a globalized economy, individuals had some predictive control over their future and did not need to constantly adjust their investments.

\section{DECREASED PREDICTABILITY IN A GLOBALIZED ECONOMY}

With the rise of an increasingly globalized economy, however, the benefits of societal canalization into safe career paths and life-course trajectories are dwindling. The multinational study consortium GLOBALIFE (Blossfeld et al., 2007; Buchholz et al., 2009) has used existing large representative data sets from 17 Organization for Economic Co-operation and Development (OECD) member states including liberal (Canada, Great Britain, and the United States), conservative (Germany, the Netherlands, and France), social-democratic (Norway, Denmark, and Sweden), family-oriented (Italy, Spain, Ireland, and Mexico), and postsocialist (Estonia, Hungary, the Czech Republic, and Poland) welfare states. These studies indicate that the major consequences of the globalization process in terms of challenges for individual agents in managing their life courses are decreasing transparency, decreasing predictability of long-term consequences of individual decisions, increasing erosion of social security, and increasing asymmetry in power relations between employers and employees.

\section{Which Societies Are Rendering Individual Agency More Versus Less Effective?}

These deregulations and destabilizations are far from uniform around the globe. Different industrialized nations show very different patterns of social mobility. According to the analyses of the GLOBALIFE group, consequences of the globalized economy depend on three aspects of the society that can be conceptualized as societal filters or buffers to globalization: (1) the flexibility of the labor market and the permeability (Hamilton, 1994) of its career tracks (relatively high in the United States, relatively low in Germany), (2) the kinds of welfare provisions offered by the state (more support offered in Germany compared to the 
United States), and (3) the role of the family in buffering economic setbacks (e.g., unemployment; greater in Germany than in the United States) (Blossfeld et al., 2007; Buchholz, et al. 2009). These state and family-based support systems provide a filter or buffer for the impact of universal globalization processes on the individual (Hofäcker, Buchholz, \& Blossfeld, in press). Accordingly, individual agents experience greater opportunities for upward mobility in the United States compared to Germany, and a greater individual responsibility including the risk of downward mobility (Heckhausen, in press).

\section{Who is Most Vulnerable and Which Individual Resources Are Most Valuable?}

Globalization-related changes in the economy not only differ in their consequences across countries, but also differentially affect various parts of the population (Blossfeld, Buchholz, \& Hofäcker, 2006; Blossfeld \& Hofmeister, 2006; Blossfeld, Mills, \& Bernardi, 2006; Blossfeld, Mills, Klijzing, \& Kurz, 2005; Buchholz et al., 2009). The group hardest hit by increasing lack of transparency and greater uncertainty about one's life-course trajectory are younger adults just entering the workforce (Blossfeld, Klijzing, Mills, \& Kurz, 2005). They earn lower incomes and are much more likely to work in part-time or short-term jobs, often without or with fewer benefits than full-time jobs (i.e., health insurance, social security, retirement benefits). We know from other work (Dooley, 2003) that beyond the immediate consequences of poverty the mental health consequences of unemployment and underemployment of youth are severe, including such outcomes as plummeting self-esteem, depression, and substance abuse. Other groups severely affected are women, particularly those who moved in and out of the workforce as they raised children (Blossfeld \& Hofmeister, 2006) and older adults (Blossfeld, Buchholz, et al., 2006). The group relatively protected from globalization effects is men in the core workforce.

As a general consequence of the decreased predictability, greater permeability of career paths, and uncertainty of long-term careers that comes with globalization processes across different countries, the role of a general education as a form of personal capital has become ever more important (Blossfeld, Klijzing, et al., 2005; Bynner, 2005; Bynner \& Parsons, 2002; Mills \& Blossfeld, 2003). Intellectual skills of reading, writing, mathematics, computer literacy, and knowledge of information technology are core requirements in a wide variety of careers and industries. Moreover, advanced educational degrees reflect higher level intellectual abilities, problem-solving and self-regulatory skills, and an ability to acquire substantial expertise in a specific area over a reasonable amount of time. All these characteristics should be highly attractive for employers of professionals. However, again countries differ greatly regarding the permeability of their educational systems. Germany has the least permeable system among 
western industrialized societies, with its early separation (typically after Grade 4) into three tiers with few support systems for crossing over. Empirical evidence shows that the educational system in Germany preserves social inequality to a greater extent than any other educational system, so that youth in Germany are the least likely to overcome the social status of their parents (Schnabel, Alfed, Eccles, Köller, \& Baumert, 2002). In contrast, the educational system in the United States provides greater permeability, particularly in states that have a well-developed system of community colleges that have articulation agreements with 4-year colleges. A prime example is the State of California with its Master Plan in Higher Education that is designed to facilitate permeability between community colleges, California State Universities, and the campuses of the University of California (California Master Plan, 1960).

Many youth respond to acute economic crisis, but also to the more general and slowly increasing uncertainty associated with globalization, by delaying their entry into the labor market (Bynner, 2005; Cote \& Bynner, 2008). Instead, they spend a larger part of their young adulthood in educational institutions pursuing educational degrees that may hold better promise for future long-term employment in higher paid careers. Life-course sociologists have argued that strategies of delaying employment and family foundation in favor of higher education is typically not an indicator of self-development and identity search (Cote \& Bynner, 2008), as Jeffrey Arnett (2000) proposed in his analyses of "emerging adulthood." Instead, leading life-course sociologists of youth and early adulthood argue that these changing strategies reflect a rational and oftentimes desperate response to the increase in uncertainty, long-term predictability, and decreasing value of highly specialized and nontransferable knowledge and training (Bynner, 2005; Cote \& Bynner, 2008; Heinz, 2008).

What about the differences in personality that affect individual agency in development? Surely, motivational differences in terms of aspirations, commitment, and self-regulatory strategies can work as resources for social mobility, but how do these characteristics interplay with societal differences? The evidence from the GLOABLIFE group suggests that the role of personal resources in terms of aptitude, education, and motivational self-regulatory skills can be expected to be greatest in liberal welfare states (e.g., United States of America), where not only the flexibility and opportunities for upward mobility is high, but also individual responsibility is high with low support from the community (Schoon, 2007). Such societal settings favor individuals with high ambitions and the motivational propensity for high investments (selective primary control) and strong commitment (selective secondary control). Such highly and ambitiously motivated individuals are more likely to overcome the status of their family, particularly when opportunities for upward mobility are institutionalized in the educational or career system, as is the case in the more elaborated multiplecollege systems as in California. 
The opportunities offered in conservative and family-oriented welfare states are critically different, in that they provide far less flexibility and efficacy to the individual agent. These more conservative welfare systems require of the individual to fit in with existing opportunities for their social and educational background, and to align themselves with the "insiders" who already hold stable employment and serve as gate-keepers (Blossfeld, Klijzing, et al., 2005; Buchholz et al., 2009). Those individuals who are content to strive for goals that are closely calibrated to what they already achieved (e.g., previous school grades) do best in these societal settings of conservative and family-oriented welfare states.

\section{INDIVIDUAL ASPIRATIONS DURING THE TRANSITION TO ADULTHOOD IN TWO SOCIETAL SETTINGS}

The transition to adulthood is likely the most consequential of the human life course, because this is when individuals move away from their families or origin and pursue their own social destiny. ${ }^{1}$ Educational background and social class of parents become less influential after high school compared to the school years (Chang, Greenberger, Chen, Heckhausen, \& Farruggia, in press). In modern societies, the transition to adulthood involves great chances for upward mobility, but also great risks for downward mobility.

According to our motivational theory of life-span development, individual agency in developmental contexts is organized in action cycles. As shown in Figure 1, these action cycles constitute a phase of selecting a goal and level of aspiration, entering the action phase when the goal is actively pursued by strategies of primary and secondary control, experiencing progress toward success or obstacles, deciding on goal disengagement after success or insurmountable failure (deadline), and moving on to the next goal cycle. The focus of the two longitudinal studies reported in this article is on the phase of goal selection and on goal engagement.

\section{Calibration Versus Boundless Optimism}

The selection of goals for the transition to adulthood can match the already attained status (i.e., tier or track in educational system, grade point average

\footnotetext{
${ }^{1}$ It should be noted that, although leaving the parental household is still typical, current economic conditions prompt some young adults to stay with their family of origin until they can economically support themselves, others return when their marriage fails, and in some countries single offspring (e.g., single sons in Italy) live with their parents well into adulthood.
} 


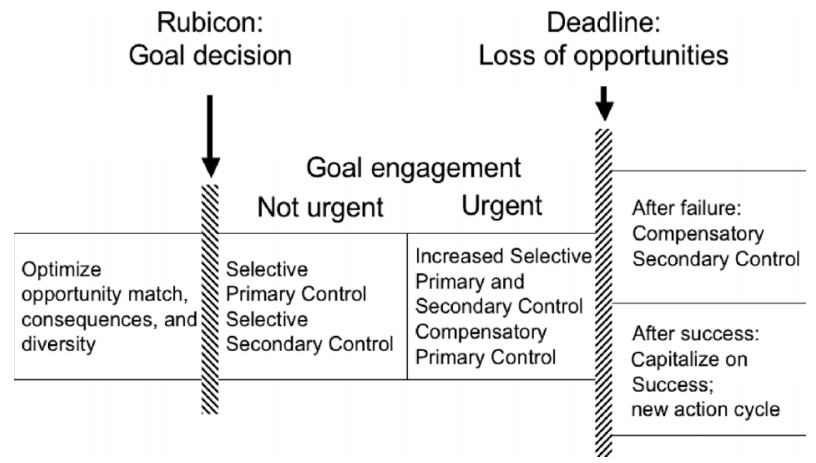

FIGURE 1 Action-phase model of developmental regulation (adapted from Heckhausen, 1999).

[GPA]) more or less closely. If the match is close, the youth will not endeavor to move up much in the system of social stratification. A strategy of goal choice that matches the individual's status and resources most closely would be adaptive under societal conditions of low permeability and great segmentation of educational and vocational tracks, as in Germany. On the other hand, the match can be loose, for example when youth entertain educational ambitions far beyond their current achievement level. We expect that such high ambitions would be more adaptive in the United States, and particularly in settings that encourage transfer and progress upward across educational institutions (e.g., community colleges to 4-year colleges) such as in the State of California.

The two kinds of transition we have been studying are (1) the transition into a vocational training position (3-year apprenticeship) after finishing the middle-tier school (i.e., Realschule) in the German three-tier high-school system and (2) the transition from the senior year in U.S. high-school into college and/or work.

\section{Germany: Transition From High School to Vocational Training}

The German secondary education system is three-tiered. Only the highest tier ("Oberschule") leads to college, with some graduates opting for the more prestigious apprenticeships in white-collar (e.g., banking, insurance) or laboratory careers (e.g., chemistry technician, medical technician). The lowest tier (i.e., "Hauptschule") typically leads into a "career" as an unskilled worker or into the least prestigious vocational training positions (e.g., in construction). The middle tier, "Realschule," leads to a graduation after grade 10 (i.e., "Mittlere Reife"), which qualifies for applying to vocational apprenticeship positions. An apprenticeship typically comprises 3 years of highly qualified and regulated training in 
a vocational trade that is combined with schooling in related fields during 2 days a week. This system of vocational training provides an organized transition into work life for German youth not heading for college, a societal institution sorely missed by the "forgotten half" in the United States (Hamilton, 1990).

With the changes associated with a globalized economy, however, German companies have become less invested in training highly qualified workers for their own work force, and thus apprenticeship positions have become scarce. Potential employers use grade average information as well as their own tests and interviews to select youth for their scarce apprenticeship slots. The youths graduating from the middle tier of German high school need to avoid overaspirations (i.e., aspiring for apprenticeships in a more prestigious field with a weak GPA) to get any apprenticeship. On the other hand, aiming too low (i.e., for an apprenticeship in an unprestigious field with a strong GPA) can compromise a youth's long-term prospects for a vocational career with promotion potential because vocational tracks are not as permeable as in the United States. The ideal choice of a range of apprenticeships to apply for is to calibrate the vocational aspirations closely to one's school performance.

Seven hundred and sixty-eight students from two East and two West Berlin middle-tier schools (Realschule) took part in a longitudinal study, with one school in each part of Berlin servicing a lower-class and one a middle-class neighborhood. Three cohorts of youth were followed at 2 monthly intervals throughout the 10th (final) grade of school as well as 2 years after graduation. The study was funded by the German Research Foundation.

We correlated the school achievement as measured by grades in core subjects (mathematics, German, history) with the occupational prestige of the youth's vocational aspirations (which apprenticeships are you interested in?). It is important to note that school achievement and vocational aspirations were assessed in a locally valid way, by standardizing the school grades within school, and by using a vocational prestige reference scale that was based on data collected in the same sample (Tomasik \& Heckhausen, 2006). As shown in Figure 2, the youth expressed vocational aspirations that in terms of their relative social prestige were correlated with their relative school achievement (Heckhausen \& Tomasik, 2002). In other words, students allowed their school grades to guide their selection of vocations they are interested in $(r=.37)$.

Did this strategy of taking into account one's school achievement when selecting vocational aspirations lead to better outcomes? First, it is trivial that students with relatively low aspirations were more likely to obtain an apprenticeship, because they inherently have a higher probability of success. The question was whether students were successful in optimizing the chances of obtaining a relatively prestigious vocational training position given their school grades. In analyses utilizing the bimonthly data collections during Grade 10, we investigated trajectories most likely to result in apprenticeships with relatively high 


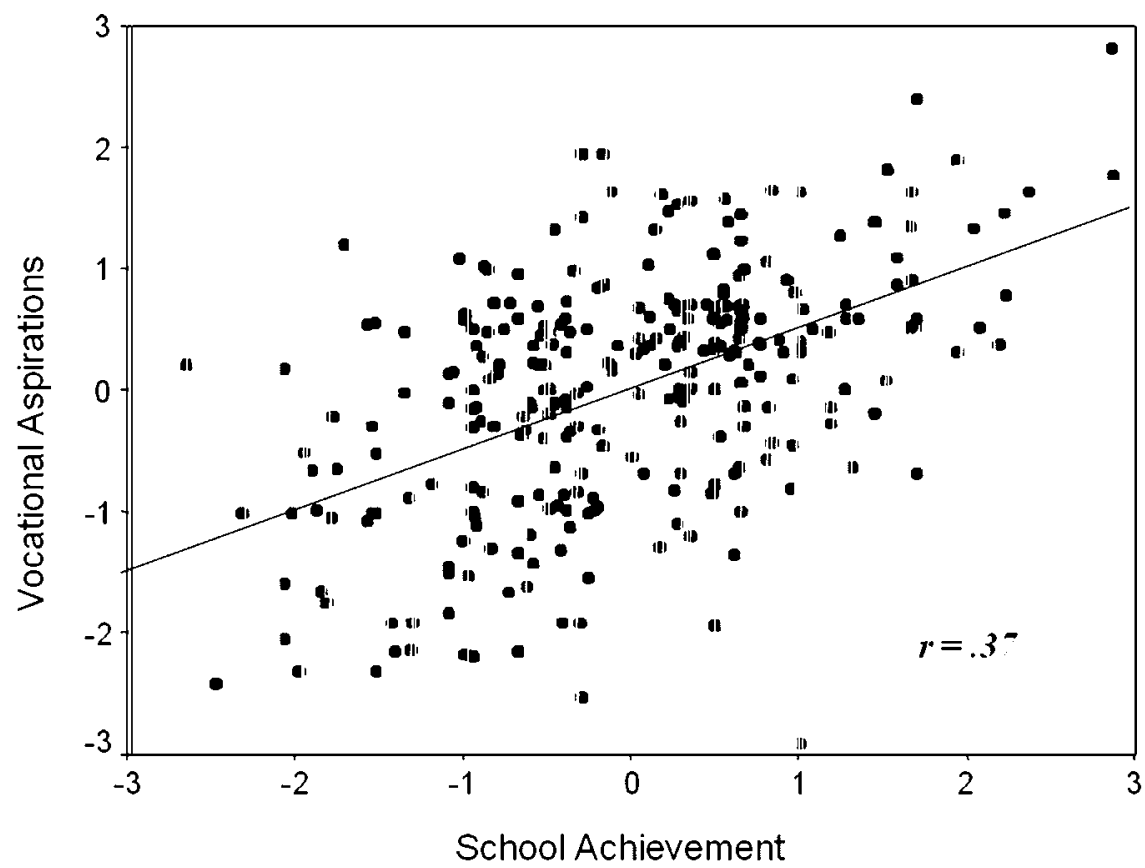

FIGURE 2 Bivariate distribution of school achievement and vocational aspiration (adapted from Heckhausen \& Tomasik, 2002).

vocational prestige given a youth's level of school achievement. We expected that such trajectories would start slightly above one's own achievement level and then adjust downward until an apprenticeship is obtained (Tomasik, Hardy, Haase, \& Heckhausen, 2009). In other words, youth would be somewhat optimistic about their chances to get an apprenticeship slightly out of their reach, and then if that proved unsuccessful, adjust their ambitions downward. Indeed we found such a pattern, and interestingly this pattern pertained particularly to those youth who expressed the strongest control strivings for goal engagement (selective primary control and selective secondary control) and the lowest levels of goal disengagement (compensatory secondary control). For girls, high goal engagement with searching for an apprenticeship was found to be critical for their success in attaining an apprenticeship, and also predictive of positive changes in affective well-being for girls and boys (Haase, Heckhausen, \& Köller, 2008). Finally, for those students who experienced a severe negative life event (e.g., death or life-threatening illness of a close relative, parental divorce) goal striving for an apprenticeship suffered, unless the youth employed specific strategies of selective secondary control that enhanced the volitional commitment 
to the goal (Poulin \& Heckhausen, 2007). The negative event-induced drop in goal striving was mediated by decreased beliefs in the effectiveness of behavioral means to overcome obstacles in career striving.

\section{United States: Transition From High-School to College/Work}

The educational system in the United States differs fundamentally from the German system in that it is integrated until high school graduation, whereas the German system is three-tiered starting at fourth grade (in some of the German states sixth grade). In the German system very early decisions that can be expected to be heavily influenced by the parents and their educational background lead to institutionally segregated paths of schooling that amplify students' achievement differences, whereas decisions about education in the United States appear much later during late adolescence, when youth can have more of their own input into the decision (Schnabel et al., 2002). The key difference between institutions of secondary education in the United States and Germany is that the U.S. educational system requires later decisions that do not constrain upward mobility by formalized institutional barriers as it does in Germany. To the contrary and particularly in California, the college system provides postsecondary educational opportunities. For the State of California, these opportunities are regulated by the California Master Plan for Higher Education in such a way as to allow the individual to follow a step-by-step upward mobility (California Master Plan, 1960). In particular, the Master Plan include a "transfer function" for community college students, who will not only be guaranteed a space in university (UC or Cal State) as long as they are residents, attain a certain GPA, and apply on time, but will also be given priority over incoming freshman from high school. Moreover, a high school degree is not required for entry into community colleges in California, and any student who is "capable of benefitting from instruction" can enroll. The California Master Plan thus provides opportunities for highly ambitious students to make their way upward step by step from humble beginnings to high-flying educational qualifications.

However, the U.S. high school system has its own social inequalities, which reflect much larger social differences than the European societies, and derail many youth from even getting close to a high school degree. High schools in different neighborhoods vary greatly in quality, because school funding is largely dependent upon home property values of the school district, thus closely reflecting differences in resident income. As a consequence, high schools in neighborhoods of varying social-economic status differ greatly in their quality of instruction, the number of drop-outs, and the number of graduates that go on to enroll in 4-year colleges. These disadvantages make it harder for students from lower-income neighborhoods to take advantage of the institutional opportunities to climb upwards in the system. In addition, youth from families with generally 
lower educational attainments are disadvantaged in their educational prospects for various reasons, including parental support, advice, and modeling (Eccles \& Wigfield, 2002; Sewell \& Shah, 1968), and peer influences (Goldsmith, 2004).

A total of 1183 high school seniors in the Los Angeles Unified School District were surveyed in our study of the transition after high school. We tracked them longitudinally and followed up with phone interviews and written questionnaires $1,2,3$, and 4 years after graduation (Chang, Chen, Greenberger, Dooley, \& Heckhausen, 2006; Chang et al., in press; Heckhausen, Chang, \& Lessard, 2007). It was striking in comparison to the German sample that vocational and particularly educational expectations were universally high. As shown in Figure 3, a large majority of the youth anticipated completing a bachelor's degree or more (i.e., complete graduate school), even if their own senior-year grades were as low as "Cs and lower." Expectations pertaining to either community college or graduate school were more adjusted to the youths' actual grades.

In an educational system that is more segregated and less permeable (Hamilton, 1994), such high aspirations would lead to unrealistic choices and failure. However, in this Californian sample the youth with the most ambitious educational expectations ultimately succeeded in enrolling in and completing 4-year college degrees. To capture the degree of individual ambitiousness of educational expectations, we used an index of grades-adjusted educational expectation that was based on the youths' expectations regarding the highest level of education they

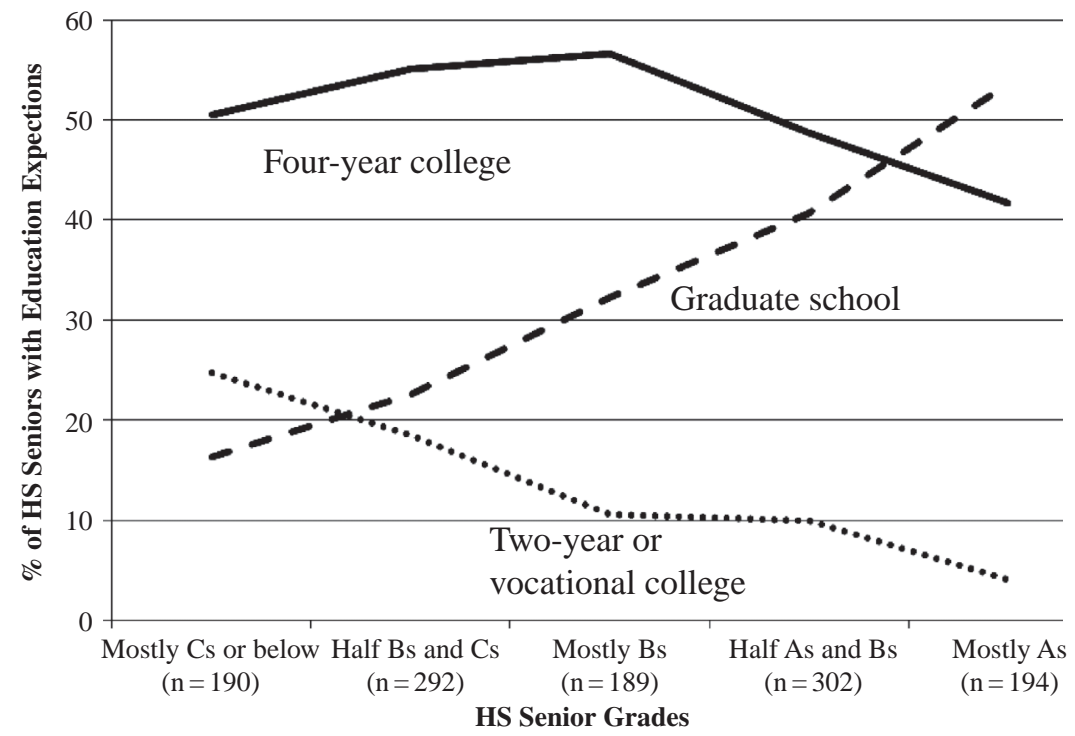

FIGURE 3 Educational expectations of U.S. high-school seniors at different levels of school performance $(N=1,167)$. 


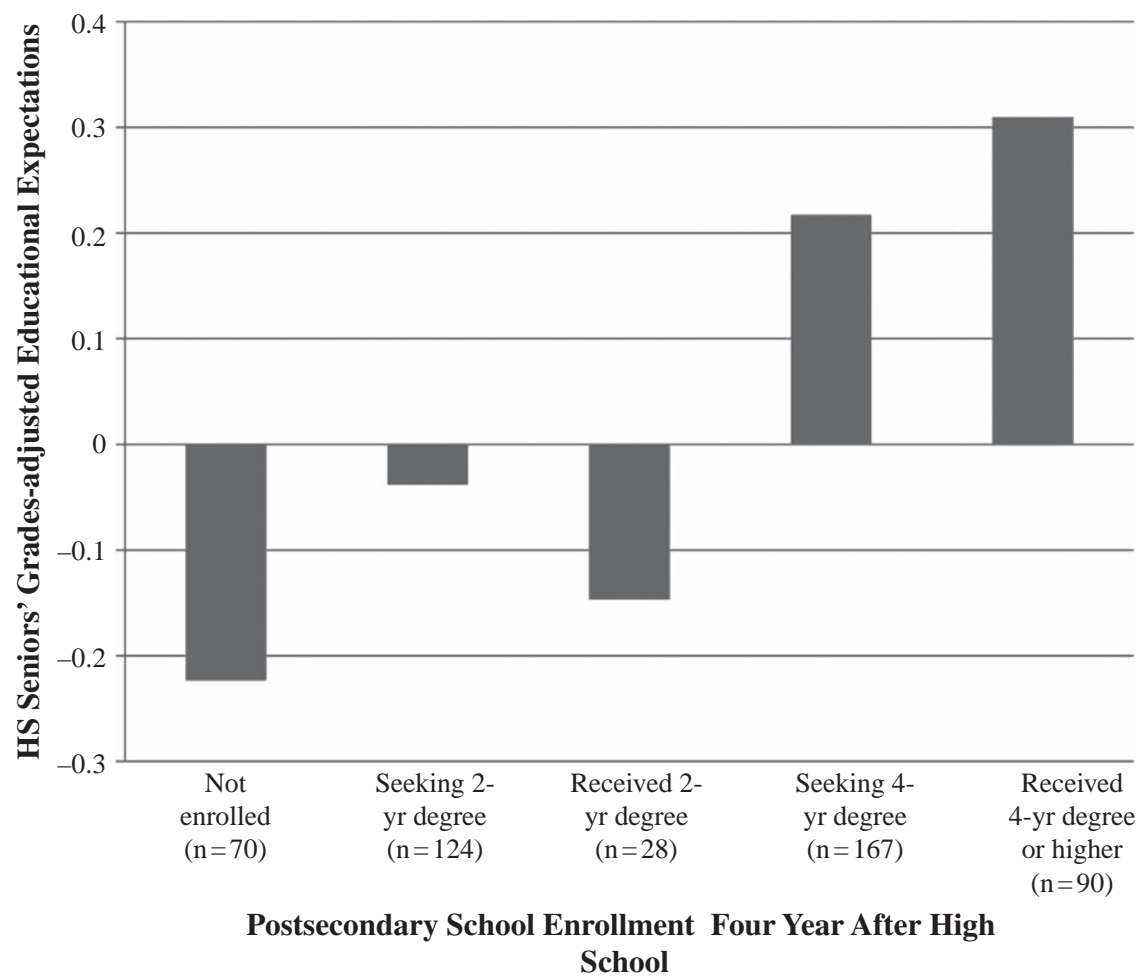

FIGURE 4 Grade-adjusted educational expectations assessed during senior year of youth attaining different levels of educational status four years after graduating from high school $(N=479)$.

will attain and centering them within the group of other students at the same level of high school performance assessed as school grades. This way, a direct assessment of the ambitiousness in educational expectations, adjusting for school performance, was achieved. Figure 4 shows the grade-adjusted educational expectations during the senior year of high school of youth attaining different levels of education 4 years after graduating from high school. There is an almost linear relationship between the ambitiousness of educational expectations in the senior year and actual educational attainment four years later.

\section{SUMMARY}

An integration of sociological perspectives and a motivational psychology approach to the life course suggest that individual ambition is more helpful in 
overcoming social inequality in societies that provide greater permeability of educational tracks and that facilitate upward mobility well into young adulthood. Because of the enhanced importance of educational qualifications under the conditions of a globalized economy, these societal differences are more consequential for individual life courses than ever. The different educational systems in Germany and the United States in terms of permeability of educational tracks and opportunities for step-by-step upward mobility through the system provide better opportunities in the United States (particularly in California) to the individual agent to aim for upward mobility. In Germany, aspirations, to be effective, need to be calibrated to one's current status and resources (e.g., in terms of school achievement). By contrast, individuals' aspirations in the educational system of California can depart significantly from one's current status and in fact are most effective when substantially overreaching. Once again, the topic of ambition that Orville Gilbert Brim so wisely championed that reveals the powers and limits of human agency in societal context.

\section{REFERENCES}

Arnett, J. J. (2000). Emerging adulthood: A theory of development from the late teens through the twenties. American Psychologist, 55, 469-480.

Baltes, P. B. (1987). Theoretical propositions of life-span developmental psychology: On the dynamics between growth and decline. Developmental Psychology, 23, 611-626.

Baltes, P. B., \& Baltes, M. M. (1990). Psychological perspectives on successful aging: The model of selective optimization with compensation. In P. B. Baltes \& M. M. Baltes (Eds.), Successful aging: Perspectives from the behavioral sciences (pp. 1-34). New York: Cambridge University Press.

Blossfeld, H.-P., Buchholz, S., \& Hofäcker, D. (2006). Globalization, uncertainty and late careers in society. London: Routledge.

Blossfeld, H.-P., Buchholz, S., Hofäcker, D., Hofmeister, H., Kurz, K., \& Mills, M. (2007). Globalisierung und die Veränderung sozialer Ungleichheiten in modernen Gesellschaften [Globalization and the change of social inequality in modern societies]. Kölner Zeitschrift für Soziologie und Sozialpsychologie, 59, 667-691.

Blossfeld, H.-P., \& Hofmeister, H. (2006). Globalization, uncertainty and women's careers in international comparison. Cheltenham, UK: Edward Elgar.

Blossfeld, H.-P., Klijzing, E., Mills, M., \& Kurz, K. (Eds.). (2005). Globalization, uncertainty and youth in society. London: Routlegde.

Blossfeld, H.-P., Mills, M., \& Bernardi, F. (2006). Globalization, uncertainty and men's careers in international comparison. Cheltenham, UK: Edward Elgar.

Blossfeld, H.-P., Mills, M., Klijzing, E., \& Kurz, K. (2005). Globalization, uncertainty and youth in society. London: Routledge.

Brandtstädter, J. (2008). Agency in developmental settings of modernity: The dialectics of commitment and disengagement. Unpublished manuscript. University of Trier, Trier, Germany.

Brim, O. G. (1992). Ambition: How we manage success and failure throughout our lives. New York: Basic Books.

Buchholz, S., Hofäcker, D., Mills, M., Blossfeld, H.-P., Kurz, K., \& Hofmeister, H. (2009). Life courses in the globalization process: The development of social inequalities in modern societies. European Sociological Review, 25, 53-71. 
Bynner, J. M. (2005). Rethinking the youth phase of the life course: The case for emerging adulthood? Journal of Youth Studies, 8, 367-384.

Bynner, J. M., \& Parsons, S. (2002). Social exclusion and the transition from school to work: The case of young people not in education, employment or training (NEET). Journal of Vocational Behavior, 60, 289-309.

The California master plan for higher education, 66010.1-66010.8 C.F.R. (1960).

Carstensen, L. L. (1993). Motivation for social contact across the life-span: A theory of socioemotional selectivity. In J. Jacobs (Ed.), Nebraska symposium on motivation (Vol. 40, pp. 205-254). Lincoln: University of Nebraska Press.

Chang, E. S., Chen, C., Greenberger, E., Dooley, D., \& Heckhausen, J. (2006). What do they want in life? The life goals of a multi-ethnic, multi-generational sample of high school seniors. Journal of Youth and Adolescence, 35, 321-332.

Chang, E. S., Greenberger, E., Chen, C., Heckhausen, J., \& Farruggia, S. P. (in press ). Non-parental adults as social resources in the transition to adulthood. Journal of Research on Adolescence.

Cote, J. E. (2002). The role of identity capital in the transition to adulthood: The individualization thesis examined Journal of Youth Studies, 5, 117-134.

Cote, J. E., \& Bynner, J. M. (2008). Changes in the transition to adulthood in the UK and Canada: The role of sturcutre and agency in emergeing adulthood. Journal of Youth Studies, 11, 251-268.

Dooley, D. (2003). Unemployment, underemployment, and mental health: Conceptualizing employment status as a continuum. American Journal of Community Psychology, 32, 9-20.

Eccles, J. S., \& Wigfield, A. (2002). Motivational beliefs, values and goals. Annual review of psychology, 53(1), 109-132.

Evans, K., \& Heinz, W. R. (1994). Becoming adults in England and Germany. London: AngloGerman Foundation.

Furlong, A., Cartmel, F., Biggart, A., Sweeting, H., \& West, P. (2006). Social class in an individualised society. Sociology Review, 15, 28-32.

Goldsmith, P. A. (2004). Schools' racial mix, students' optimism, and the black-white and Latino-white achievement gap. Sociology of Education, 77, 121-147.

Haase, C. M., Heckhausen, J., \& Köller, O. (2008). Goal engagement in the school-to-work transition: Beneficial for all, particularly for girls. Journal of Research on Adolescence, 17, 671-698.

Hamilton, S. F. (1990). Apprenticeship for adulthood: Preparing youth for the future. New York: Free Press.

Hamilton, S. F. (1994). Employment prospects as motivation for school achievement: Links and gaps between school and work in seven countries. In R. K. Silbereisen \& E. Todt (Eds.), Adolescence in context: The interplay of family, school, peers, and work in adjustment (pp. 267-303). Cambridge, UK: Cambridge University Press.

Heckhausen, J. (1999). Developmental regulation in adulthood: Age-normative and sociostructural constraints as adaptive challenges. Cambridge, UK: Cambridge University Press.

Heckhausen, J. (in press ). Globalization, social inequality, and individual agency in human development: Social change for better or worse? In R. K. Silbereisen \& X. Chen (Eds.), Social change and human development: Concepts and results. Thousand Oaks, CA: Sage.

Heckhausen, J., \& Brim, O. G. (1997). Perceived problems for self and others: Self-protection by social downgrading throughout adulthood. Psychology and Aging, 12, 610-619.

Heckhausen, J., Chang, E. S., \& Lessard, J. (2007, August). Developmental repulation in German and American adolescents during the transition from school to work. Paper presented at the 13th European Conference an Developmental Psychology, Jena, Germany.

Heckhausen, J., \& Farruggia, S. P. (2003). Developmental regulation across the life span: A control theory approach and implications for secondary education. British Journal of Educational Psychology, Monograph Series II: Psychological Aspects of Education - Current Trends, 1, 85-102.

Heckhausen, J., \& Heckhausen, H. (2008). Motivation and development. In J. Heckhausen \& H. Heckhausen (Eds.), Motivation and action (pp. 384-443). New York: Cambridge University Press. 
Heckhausen, J., \& Schulz, R. (1993). Optimization by selection and compensation: Balancing primary and secondary control in life span development. International Journal of Behavioral Development, 16, 287-303.

Heckhausen, J., \& Schulz, R. (1995). A life-span theory of control. Psychological Review, 102, 284-304.

Heckhausen, J., \& Schulz, R. (1999). Biological and societal canalizations and individuals' developmental goals. In J. Brandtstädter \& R. Lerner (Eds.), Action and self-development: Theory and research through the life-span (pp. 67-103). Thousand Oaks, CA: Sage.

Heckhausen, J., \& Tomasik, M. J. (2002). Get an apprenticeship before school is out: How German adolescents adjust vocational aspirations when getting close to a developmental deadline. Journal of Vocational Behavior, 60, 199-219.

Heinz, W. R. (2002). Self-socialization and post-traditional society. In R. A. Settersten \& T. J. Owens (Eds.), Advances in life-course research: New frontiers in socialization (pp. 41-64). New York: Elsevier.

Heinz, W. R. (2008). The many faces of emerging adulthood: Social pathways from youth to adulthood.Unpublished manuscript, Bremen, Germany.

Hitlin, S., \& Elder, G. H., Jr. (2007). Time, self, and the curiously abstract concept of agency Sociological Theory, 25, 170-191.

Hofäcker, D., Buchholz, S., \& Blossfeld, H.-P. (in press ). Globalization, institutional filters and changing life course patterns in modern societies: A summary of the results from the GLOBALIFE-project. In R. K. Silbereisen \& X. Chen (Eds.), Social change and human development: Concepts and results. London: Sage.

Little, B., Salmela-Aro, K., \& Phillips, S. (2007). Personal project pursuit: Goals, action, and human flourishing. Mahwah, NJ: Lawrence Erlbaum.

Mayr, E. (1974). Behavior programs and evolutionary strategies. American Scientist, 62, 650-659.

Mills, M., \& Blossfeld, H.-P. (2003). Globalization, uncertainty and changes in the early life course. International Journal of Behavioral Development, 2, 188-218.

Nurmi, J.-E., \& Salmela-Aro, K. (2006). What works makes you happy: The role of personal goals in life-span development. In M. Csikszentmihalyi \& I. S. Csikszentmihalyi (Eds.), A life worth living: Contributions to positive psychology (pp. 182-199). New York: Oxford University Press.

Poulin, M., \& Heckhausen, J. (2007). Stressful events compromise goal striving during a major life transition. Motivation and Emotion, 31, 300-311.

Schnabel, K. U., Alfed, C., Eccles, J. S., Köller, O., \& Baumert, J. (2002). Parental influence on students' educational choices in the United States and Germany: Different ramifications-same effect? Journal of Vocational Behavior, 60, 178-198.

Schoon, I. (2007, August). School engagement and transitions into adult roles. Paper presented at the European Conference for Developmental Psychology. Jena, Germany.

Schulz, R., \& Heckhausen, J. (1996). A life-span model of successful aging. American Psychologist, $51,702-714$.

Schulz, R., Wrosch, C., \& Heckhausen, J. (2003). The life-span theory of control: Issues and evidence. In S. H. Zarit, L. I. Pearlin \& K. W. Schaie (Eds.), Personal Control in social and life course contexts: Societal impact on aging (pp. 233-262). New York: Springer.

Sewell, W. H., \& Shah, V. P. (1968). Social class, parental encouragement, and educational aspirations. American Journal of Sociology, 73, 559-572.

Tomasik, M. J., Hardy, S., Haase, C. M., \& Heckhausen, J. (2009). Adjustment of vocational aspirations when approaching a developmental deadline. Journal of Vocational Behavior, 74, $38-46$

Tomasik, M. J., \& Heckhausen, J. (2006). Sozialprestige von Ausbildungsberufen aus der Sicht von Realschülern [Social prestige of occupations from the perspective of high school students]. Zeitschrift für Sozialpsychologie, 37, 259-273. 